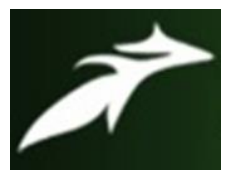

Prince Kumar et al, International Journal of Advances in Agricultural Science and Technology,

Vol.7 Issue.12, December-2020, pg. 37-44

ISSN: 2348-1358

Impact Factor: 6.057

NAAS Rating: 3.77

\title{
ADOPTION BEHAVIOUR OF \\ RESPONDENTS TOWARDS ORGANIC VEGETABLE PRODUCTION PRACTICES IN NAWADA DISTRICT OF BIHAR
}

\author{
Prince Kumar ; Dr. Jahanara ${ }^{2}$ \\ M.Sc. Scholar, Head of the Department \\ Department of Agricultural Extension \& Communication \\ Sam Higginbottom University of Agricultural Technology \& Sciences, Prayagraj (211007)
}

DOI: 10.47856/ijaast.2020.v07i12.006

\begin{abstract}
In Bihar movement of organic farming gaining support from farmers as well as consumers. Now a day's consumers are also becoming conscious about healthy and nutritious food. The farmers from different area also adopting some organic farming practices. Hence the present study was undertaken to find out the adoption level of respondents towards organic vegetable production practices was conducted in Nawada block of nawada district. The 120 respondents were selected from 6 villages of nawada district by proportionate random sampling method. The data were collected by personal interview method with the help of pre-structured interview schedule. The study revealed that majority of the respondents had medium level of socio-economic status. It also revealed that theadoption level towards organic production practices was medium to high level respectively and this is a positive sign for increasing the awareness about organic vegetable (brinjal) production so as to provide the future generation a healthy and chemical free diet.
\end{abstract}

KEYWORDS- Organic vegetable production practices, Adoption level, Socio-economic profile

\section{INTRODUCTION}

In view of growing awareness of health and environment issues, organic farming especially of vegetables is gaining momentum across the world and emerging fast as an attractive source of rural income generation. Organic products are increasingly preferred in developed countries and in major urban centers in India. There is high demand for organic food in domestic and international market which is growing around 20-25 percent annually; as aresult the area under organic farming has been increasing consistently. In Bihar movement of organic farming gaining support from farmers as well as consumers. Now a day's consumers are also becoming conscious 


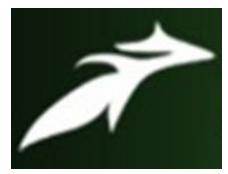

Prince Kumar et al, International Journal of Advances in Agricultural Science and Technology, Vol.7 Issue.12, December-2020, pg. 37-44

ISSN: 2348-1358

Impact Factor: 6.057

NAAS Rating: 3.77

about healthy and nutritious food. The farmers from different area also adopting some organic farming practices. Hence the present study was undertaken to find out the level of knowledge and attitude of respondents towards organic vegetable production practices in Nawada district of Bihar.

\section{RESEARCH METHODOLOGY:}

The present study was conducted in Nawada district of Bihar state which is purposively selected based on research objective and criteria of sampling concerning adoption behaviour of respondents towards organic vegetable production practices. In Nawada block of Nawada district, 6 villages were selected randomly for the present study. Total 120 number of respondents were selected from each selected village for the present study. The primary data was collected with the help of pre-tested- structured interview schedule, designed especially in the light of objectives, whereas secondary data was collected from sources like thesis, journals, literatureetc. Percentage analysis were done to analyse the data. And ranking was done according to results obtained.

Data collected were qualitative as well as quantitative. Qualitative data were converted into quantitative data. The quantitative data were tabulated on the basis of logical categorization method. Percentage, Coefficient correlation and Microsoft Excel were used for analysis purpose.

\section{RESULTS AND DISCUSSION}

\section{Distribution of Socio-economic Profile Of the respondents}

Table-1: Distribution of the respondents according to their Age.

\begin{tabular}{|l|l|l|l|}
\hline S.I. No. & \multicolumn{1}{|c|}{ Age (years) } & Frequency & Percentage \\
\hline $\mathbf{1}$ & Young (25-35 years) & 37 & 30.83 \\
\hline $\mathbf{2}$ & Middle age (36-55) & 57 & 47.5 \\
\hline $\mathbf{3}$ & Old (above 55) & 26 & 21.66 \\
\hline & Total & $\mathbf{1 2 0}$ & $\mathbf{1 0 0}$ \\
\hline
\end{tabular}

It is seen in the table 1 that 47.5 per cent of the respondents were of middle age group followed by young age group 30.83 per cent and old age group 21.66 per cent respectively.

Table-2: Distribution of the respondents according to their Education.

\begin{tabular}{|l|l|l|l|}
\hline SI no. & Particulates & Frequency & Percentage \\
\hline 1 & Illiterate & 18 & 15 \\
\hline 2 & Primary & 75 & 62.5 \\
\hline 3 & High school \& above & 27 & 22.5 \\
\hline & Total & 120 & 100 \\
\hline
\end{tabular}




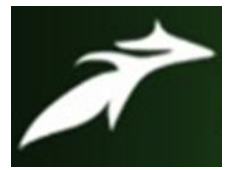

Prince Kumar et al, International Journal of Advances in Agricultural Science and Technology,

Vol.7 Issue.12, December-2020, pg. 37-44

ISSN: 2348-1358

Impact Factor: 6.057

NAAS Rating: 3.77

The above table shows that 62.5 percent respondents were primary school followed by high school \& above and 15 percent respondents were Illiterate respectively.

Table-3: Distribution of the respondents according to their Annual income.

\begin{tabular}{|l|l|l|l|}
\hline $\begin{array}{l}\text { SI } \\
\text { no. }\end{array}$ & Particulates & Frequency & Percentage \\
\hline 1 & Low (Up to Rs. 100000) & 46 & 38.33 \\
\hline 2 & $\begin{array}{l}\text { Medium (Rs.100001- } \\
\text { 200000) (more than }\end{array}$ & 25 & 40.84 \\
\hline 3 & $\begin{array}{l}\text { High } \\
\text { Rs.200000) }\end{array}$ & 120 & 100 \\
\hline & Total 23 \\
\hline
\end{tabular}

It is clear from the above table that 40.84per cent respondents have Annual income betweenRs.100001-200000, 38.33per cent respondents have up to Rs.100000, and 20.23per cent respondents have income more than Rs. 200000.

Table-4: Distribution of the respondents according to their Livestock possession.

\begin{tabular}{|l|l|l|l|}
\hline $\begin{array}{l}\text { SI } \\
\text { no. }\end{array}$ & Particulates & Frequency & Percentage \\
\hline 1 & Low & 31 & 25.83 \\
\hline 2 & Medium & 69 & 57.50 \\
\hline 3 & High & 20 & 16.67 \\
\hline & Total & 120 & 100 \\
\hline
\end{tabular}

It is seen in the table 4 that 57.50 per cent of the respondents were of medium category group followed by low category group 25.83per cent and high category group 16.67 per cent respectively.

Table-5: Distribution of the respondents according to their House type.

\begin{tabular}{|l|l|l|l|}
\hline $\begin{array}{l}\text { SI } \\
\text { no. }\end{array}$ & Particulates & Frequency & Percentage \\
\hline 1 & Thatched house & 24 & 20 \\
\hline 2 & Semi-cemented & 74 & 61.67 \\
\hline 3 & Cemented house & 22 & 18.33 \\
\hline & Total & 120 & 100 \\
\hline
\end{tabular}

The above table reveals that 61.67 per cent respondents live in semi-cemented house followed by 20 per cent respondents live in thatched house and 18.33 per cent respondents live in cemented type of house 


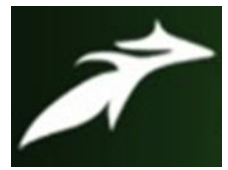

Prince Kumar et al, International Journal of Advances in Agricultural Science and Technology, Vol.7 Issue.12, December-2020, pg. 37-44

ISSN: 2348-1358

Impact Factor: 6.057

NAAS Rating: 3.77

Table-6: Distribution of the respondents according to their area under organic farming.

\begin{tabular}{|l|l|l|l|}
\hline $\begin{array}{l}\text { SI } \\
\text { no. }\end{array}$ & Particulates & Frequency & Percentage \\
\hline 1 & Low (up to 3 bighas) & 39 & 32.5 \\
\hline 2 & Medium (3 to 6 bighas) & 57 & 47.5 \\
\hline 3 & High (above 6 bighas) & 24 & 20 \\
\hline & Total & 120 & 100 \\
\hline
\end{tabular}

It is seen in the table 6 that 47.50 per cent of the respondents were of medium category group followed by low category group 32.50per cent and high category group 20 per cent respectively area under organic farming.

Table-7: Distribution of the respondents according to their Training attended.

\begin{tabular}{|l|l|l|l|}
\hline $\begin{array}{l}\text { SI } \\
\text { no. }\end{array}$ & Particulates & Frequency & Percentage \\
\hline 1 & No training & 32 & 26.67 \\
\hline 2 & Training attended & 88 & 73.33 \\
\hline & Total & 120 & 100 \\
\hline
\end{tabular}

The above table shows that 60.83 per cent respondents have attended training and other 39.17 per cent respondents have not attended any training.

Table-8: Distribution of the respondents according to their information seeking behaviour.

\begin{tabular}{|l|l|l|l|}
\hline $\begin{array}{l}\text { SI } \\
\text { no. }\end{array}$ & Particulates & Frequency & Percentage \\
\hline 1 & Low (9-15) & 24 & 20 \\
\hline 2 & Medium (16-21) & 59 & 49.67 \\
\hline 3 & High (22-27) & 37 & 30.83 \\
\hline & Total & 120 & 100 \\
\hline
\end{tabular}

It is seen in the table 6 that 49.67 per cent of the respondents were of medium category group followed by high category group 30.83per cent and low category group 20 per cent respectively according to their information seeking behaviour.

Table-9: Distribution of the respondents according to their Type of Social contacts.

\begin{tabular}{|l|l|l|l|}
\hline $\begin{array}{l}\text { SI } \\
\text { no. }\end{array}$ & Particulates & Frequency & Percentage \\
\hline 1 & Low (6-10) & 26 & 21.66 \\
\hline 2 & Medium (11-14) & 61 & 50.84 \\
\hline 3 & High (15-18) & 33 & 27.5 \\
\hline & Total & 120 & 100 \\
\hline
\end{tabular}




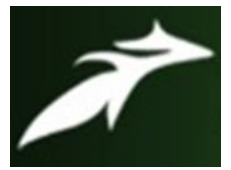

Prince Kumar et al, International Journal of Advances in Agricultural Science and Technology,

Vol.7 Issue.12, December-2020, pg. 37-44

ISSN: 2348-1358

Impact Factor: 6.057

NAAS Rating: 3.77

The data in the above table shows that most of the respondent $(50.84 \%)$ were found in medium social contacts category followed by high category $(21.66 \%)$ and low (27.5\%) social contacts category respectively.

Table-10: Distribution of the respondents according to their Extension contacts.

\begin{tabular}{|l|l|l|l|}
\hline $\begin{array}{l}\text { SI } \\
\text { no. }\end{array}$ & Particulates & Frequency & Percentage \\
\hline 1 & Low (5-8) & 47 & 39.67 \\
\hline 2 & Medium (9-12) & 53 & 44.67 \\
\hline 3 & High (13-15) & 20 & 16.66 \\
\hline & Total & 120 & 100 \\
\hline
\end{tabular}

The data in the above table shows that most of the respondent $(44.67 \%)$ were found in medium extension contacts category followed by high category $(39.67 \%)$ and low $(16.66 \%)$ extension contacts category respectively.

\section{ADOPTION LEVEL OF RESPONDENTS TOWARDS ORGANIC VEGETABLE (BRINJAL) PRODUCTION PRACTICES}

Table-11: Distribution of the respondents according to their Adoption level

\begin{tabular}{|c|c|c|c|}
\hline \multirow[t]{2}{*}{ Organic production practices } & \multicolumn{3}{|c|}{ Adoption level of respondents } \\
\hline & $\begin{array}{l}\text { Fully Adopted } \\
\text { F. (\%) }\end{array}$ & $\begin{array}{l}\text { Partially } \\
\text { Adopted } \\
\text { F. }(\%)\end{array}$ & $\begin{array}{l}\text { Not Adopted } \\
\text { F. }(\%)\end{array}$ \\
\hline \multicolumn{4}{|l|}{ For in situ management } \\
\hline Green manure & $22(18.33)$ & $61(50.84)$ & $37(30.83)$ \\
\hline Crop residues & $17(14.16)$ & $65(54.16)$ & $38(31.68)$ \\
\hline Poultry manure & $28(23.33)$ & $59(49.17)$ & $33(27.50)$ \\
\hline Urban and rural wastes & $27(22.50)$ & $58(48.33)$ & $35(29.17)$ \\
\hline Recycling the weed biomass & $28(23.33)$ & $63(52.50)$ & $29(24.17)$ \\
\hline $\begin{array}{l}\text { Recycling the agro-based industrial } \\
\text { wastes }\end{array}$ & $22(18.33)$ & $68(56.67)$ & $30(25)$ \\
\hline Use of oil industry products & $29(24.17)$ & $63(52.50)$ & $28(23.33)$ \\
\hline Fish wastes & $16(13.33)$ & $64(53.34)$ & $40(33.33)$ \\
\hline Sewage farming & $26(21.67)$ & $57(47.49)$ & $37(30.84)$ \\
\hline
\end{tabular}




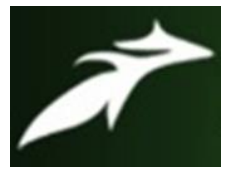

Prince Kumar et al, International Journal of Advances in Agricultural Science and Technology, Vol.7 Issue.12, December-2020, pg. 37-44

ISSN: 2348-1358

Impact Factor: 6.057

NAAS Rating: 3.77

\begin{tabular}{|c|c|c|c|}
\hline \multicolumn{4}{|l|}{ Use of pre-digested manure } \\
\hline Farm yard manure & $27(22.50)$ & $67(55.83)$ & $26(21.67)$ \\
\hline Composting & $30(25)$ & $62(51.67)$ & $28(23.33)$ \\
\hline Other livestock wastes & $25(20.83)$ & $64(53.34)$ & $31(25.83)$ \\
\hline \multicolumn{4}{|l|}{ Bio-fertilizers } \\
\hline $\mathrm{N}$-fixing agents & $30(25)$ & $61(50.84)$ & $29(24.16)$ \\
\hline P-solubilizing microbes & $20(16.67)$ & $65(54.17)$ & $35(29.16)$ \\
\hline Vermi-culture & $23(19.17)$ & $59(49.16)$ & $38(31.67)$ \\
\hline $\mathrm{N}$-fixing crop and trees & $34(28.33)$ & $49(40.84)$ & $37(30.83)$ \\
\hline \multicolumn{4}{|l|}{ Cultural methods } \\
\hline $\begin{array}{l}\text { Crop rotation with pulses for } \mathrm{N}- \\
\text { Fixation }\end{array}$ & $42(35)$ & $46(38.33)$ & $32(26.67)$ \\
\hline $\begin{array}{lllll}\text { Intercropping with pulses for } \mathrm{N}- \\
\text { Fixatin }\end{array}$ & $42(35)$ & $49(40.84)$ & $29(24.16)$ \\
\hline $\begin{array}{l}\text { Minimum tillage for nutrient } \\
\text { conservation }\end{array}$ & $29(24.16)$ & $60(50)$ & $31(25.84)$ \\
\hline $\begin{array}{l}\text { Agro-forestry methods } \text { i.e. } \text { alley } \\
\text { cropping }\end{array}$ & $25(20.84)$ & $62(51.66)$ & $33(27.50)$ \\
\hline Mulching over crops & $26(21.67)$ & $57(47.49)$ & $37(30.84)$ \\
\hline
\end{tabular}

Table-12: Distribution of respondents according to their overall Adoption level:

\begin{tabular}{|l|l|l|l|}
\hline Si.No. & Adoption level & Frequency & Percentage \\
\hline $\mathbf{1}$ & Low (21-32) & 33 & 27.50 \\
\hline $\mathbf{2}$ & Medium (33-43) & 60 & 50 \\
\hline $\mathbf{3}$ & High (44-54) & 27 & 22.50 \\
\hline & Total & 120 & 100.00 \\
\hline
\end{tabular}

The data in the above table showed that most of the respondents 50.00 per cent have medium adoption level followed by 27.50 per cent of respondents belonged to low Adoption level and 22.50 per cent fell in high adoption level. 


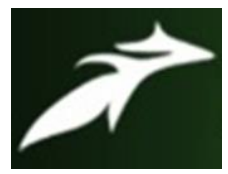

Prince Kumar et al, International Journal of Advances in Agricultural Science and Technology, Vol.7 Issue.12, December-2020, pg. 37-44

ISSN: 2348-1358

Impact Factor: 6.057

NAAS Rating: 3.77

Table-13: Relationship between socio-economic Characteristics and adoption level of sericulture farmers:

\begin{tabular}{|l|l|l|}
\hline Sl. No. & Characteristics & "r" value \\
\hline $\mathbf{1 .}$ & Age & $0.551^{*}$ \\
\hline $\mathbf{2 .}$ & Education & $0.243^{*}$ \\
\hline $\mathbf{3}$ & House type & $0.0782 \mathrm{NS}$ \\
\hline $\mathbf{4}$ & Annual income & $0.284^{*}$ \\
\hline $\mathbf{5}$ & Training attended & $0.184^{*}$ \\
\hline $\mathbf{6}$ & Livestock possession & $0.905^{*}$ \\
\hline $\mathbf{7}$ & Area under organic farming & $0.898^{*}$ \\
\hline $\mathbf{8}$ & Information seeking behaviour & $0.307^{*}$ \\
\hline $\mathbf{9}$ & Social contact & $0.332^{*}$ \\
\hline $\mathbf{1 0}$ & Extension contact & $0.304^{*}$ \\
\hline
\end{tabular}

$*=$ Significant at $\mathrm{p}=0.05, \mathrm{NS}=$ Non Significant

The data from the above table shows that Age, Education, Annual income, Training attended, Livestock possession, area under organic farming, Information seeking behaviour, Social contact, Extension contact are positively significant at $0.05 \%$ whereas house types are positive but non-significant at $0.05 \%$ to extend of adoption of the respondent respectively.

\section{CONCLUSION}

It can be concluded that most of the respondents $(50.00 \%)$ had medium level of adoption followed by low $(27.50 \%)$ and high $(22.50 \%)$ and the relationship between adoption level and socio-economic profile of respondents shows that age $\left(0.551^{*}\right)$, Education $\left(0.243^{*}\right)$, Annual income $\left(0.284^{*}\right)$, Training attended $\left(0.184^{*}\right)$, Livestock possession $\left(0.905^{*}\right)$, Area under organic farming $\left(0.898^{*}\right)$, Information seeking behaviour $\left(0.307^{*}\right)$, Social contact $\left(0.332^{*}\right)$ and Extension contacts (0.304), are positive but non-significant at $0.05 \%$ whereas House types $(0.078 \mathrm{NS})$ are positive but non-significant at $0.05 \%$ to extend of adoption of the respondent respectively. Hence it is imperative that government and to experts should take more steps like training, field demonstration, more interaction with farmers, more government schemes, loans so that more people can adopt organic vegetable production practices as it also generate lots of employments which will help in upliftment of farming society. 


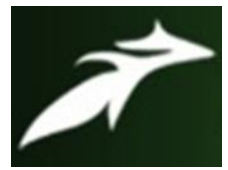

Prince Kumar et al, International Journal of Advances in Agricultural Science and Technology,

Vol.7 Issue.12, December-2020, pg. 37-44

ISSN: 2348-1358

Impact Factor: 6.057

NAAS Rating: 3.77

\section{References}

[1]. Barik AK. (2017) Organic Farming in India: Present Status, Challenges and Technological Brea through.

[2]. Bordolo, B., (2016) The future lies in organic farming. The Hindu Business Line, available at http://www.thehindubusinessline.com

[3]. Chitale, S., Bhoi, S.K., Tiwari, A., (2012). Organic rice production technology. Model training course on rice production technology. Feb., 22-29, 2012.

[4]. Jaganathan, D. (2004) Analysis of organic farming practices in vegetable cultivation in Thruvanathapuram district. M.Sc. (Ag) thesis, Kerala Agricultural University, Thrissur, 115p.

[5]. Oyesola., Olutokunbo, B., Obabire., and Ibikunle, E. (2011) Farmers" perceptions of organic farming in selected local government areas of ekiti state, Nigeria. J. of Org. Syst. 6 (1): 83-91.

[6]. Pawar, A. (2013) Eco-friendly mango production technologies in Konkan region. PhD thesis, Dr. BSKKV, Dapoli, Maharashtra. 175p.

[7]. Sharma Neetu and Kour Manpreet (2009). Organic farming-its relevance in Indian Agriculture. Rashtriya Krishi, 4(1):59-61. 